\title{
INCREASING USE OF JUNK FOOD IN NEPALESE SOCIETY, A HISTORICAL STUDY
}

\author{
Murari Krishna Gautam*
}

\begin{abstract}
Foods that are high in calories, salt, sugar and fat, but protein, vitamins and minerals are almost zero are considered as junk foods.Such foods include pizza, burgers, chowmein, bakery items, fried plain roasted food, and highly used foods with food colors and flavors. The use of such foods has increased tremendously in Nepali societyAs a result, at an early age, sugar, blood pressure, heart related diseases, kidney related problems, digestive problems, obesity related problems are appearing in Nepalis.In order to solve the health problems caused by the excessive use of junk food in Nepali society, it has become necessary to implement a clear policy to limit the consumption of junk food at the national level.
\end{abstract}

Key words: Junk foods, Obesity, Over weight, Calories, Globalization, Protein, vitamin, Hypertension

\section{Introduction}

Junk food was used for the first time in 1972 but that it owns its popularity to a novelty song "Junk Food Junkia" by Larry Groce, was popular in 1976 A D...Junk food is a food that is rich in calories but very low in protein, vitamins and minerals. Cracker jack, candycoated popcorn and peanuts was the first used as junk food. This kind of foods has high amounts of fat, sugar, salt and colors .Most types of junk food appeared in $20^{\text {th }}$ century as a result of mechanization electricity and labor saving division as well as cheaper ingredients with less nutritional value and useasing fast.It could be easily targeted to children. Commercials for junk food are mostly targeted at young children and teenagers. Long fried dishes in oil like French fry, pizza ,burger ,Chau Chau ,dalmoth, Bhujiyaa, Nikki phurandaanaetc we know as junk food. These types of foods provide more calories but less nutrients that the body needs. Therefore, due to such food, the body weight increases and the body becomes fat and the amount of fat increases unnecessarily.These foods increase the risk of heart disease and increase the risk of various diseases. In Nepali society, the practice of consuming such food has increased a lot. Junk food is on the rise, especially in urban areas. Whether in the morning for breakfast or in day time breakfast, junk food is mandatory in Nepali society. Most bakery items are used for breakfast, while star fried foods are used for breakfast. Roasted and roasted dishes are also in high demand in many places like hotels and restaurants. * Associate Professor of Saraswati Multiple Campus (Humanities Faculty: History Department), Tribhuvan University,
Nepal. 


\section{Statement of the Problem}

We have been hearing and meditating on the statement that health is wealth but in Nepali society, the taste of the tongue has been given more priority than health and junk food has been adopted as an essential food.Now a days, people's daily life has become very busy. The increasing use of junk food has found a high place in our lives as both husband and wife are involved in earning a living and there is a lack of time to prepare meals and food.People from infancy to adulthood enjoy the use of junk food. Its use has grown so much that it has wiped out our original and traditional foodThe children were able to stop enjoying the taste of innumerable basic foods like dal, rice, vegetable bread, haluwa, khir, dhido, chamre, puwa and mada.As the use of nutritious food decreases in daily life and the increasing use of junk food becomes widespread, various diseases are appearing in our society at an early age.Heartburn at the age of 20/30, Diabetes at the age of $15 / 20$, Stomach related disease at the age of digestion even after falling of stones, Unnecessary obesity in the body at an early age, etc. Health problems are due to the increasing use of junk food, due to which a large amount of money has to be spent on health treatment.

\section{Literature Review}

Junk food is tasty food that is easy to get and consume. These types of foods are low in nutrients and high in calorie Eating such foods can have a detrimental effect on the health of the consumerFlour, sugar, salt and other chemicals are widely used in the preparation of junk food.In developed countries like the US, junk food is often used.Similarly in Japan, the consumption of such food seems to be increasing due to the busyness of daily life.Increasing consumption of this type of food increases the risk of foodborne illnesses such as diabetes, hypertension, heart diseases, dental cavities, kidney disease and neurologic disorders. There are various reasons for the increasing use of junk food in which the related industries aim to produce and deliver them quickly.As more artifical colors and scents are used, such foods are more attractive, which affects childrenmore.Similarly, the industry producing such food has allocated a lot of budget in advertisement due to which its use is increasing day by day. The amount of calories in junk food is high but the amount of protein, vitamins and minerals required by the body is almost zero. These types of foods are suitable for filling the goat's stomach quickly but the body cannot get the nutrients from them. These types of foods include bread, cakes, pizza, burgers, french fries, chowmein, noodles, cheeseballs, biscuits, cookies, star-fried fried foods.Fried in too much hot oil destroys the nutrients in it, so long-term roasting and frying can destroy the nutrients in it.This type of food uses a lot of unnatural colors and flavors, so it has a long-term effect on the body.Overall, this type of food, which has a sweet taste and is easily available, seems to have played an important role in causing a variety of complex health problems.Due to which, the victims of various diseases at an early age are forced to spend huge amount of money on medical treatment and the situation of having to give up life at a young age is becoming more and more likely to be caused by the use of such food. 


\section{Methodology}

Qualitative Research Design has been used to study this subject in order to get information about the increasing use of junk food from Field Research Method, 20 houses in Banasthali area of Kathmandu have been selected and information related to it has been collected.All the information about the problem has been obtained by visiting the 20 sample houses and asking questions about how junk food has been used in daily life.For breakfast, they told to use more jam, bread, omelette, biscuits, cookies, cakes, jelly, cake, etc.It was learned that Chiura Dalmot, Bhujia, Cake ,Chaumin Noodles, Nikki, Furan Dana Bakery item etc. were used extensively for breakfast.The respondent informed that sometimes he used to order pizza, burger ,fried chicken sekuwa ,momo, potato chips etc. at home from online.

When asked can cook and eat traditional Nepali food, they said that most of the people at home do not like to cook because they do not like to eat. Thus, the question of whether the use of junk food in large quantities has a negative effect on health is due to the fact that most people have indigestion, gastric problems, pulses, excessive body weight, unnecessarily increased body weight, indigestion, problems of appetite, obesity, diabetes, diabetes. They also said that they are suffering from heart related health problems. When asked about the children Tiffin, what to send in the tiffin, most of them replied that they would send cakes, dalmot, chiura, biscuits, cookies, bakery items from home.Based on the information obtained in this way, it is clear that the use of junk food in Nepali society is more than necessary.

\section{Data Analysis}

The data obtained from the answers to the questions asked in 20 sample houses located in Banasthali area of Kathmandu has been analyzed by Content Analysis method.The use of junk food was found to be excessive, especially in the morning and day time breakfast.It can be said that 90 percent of the traditional Nepali dishes used as lunch have been replaced by junk food.Due to the easy availability of junk food in the market, it was found that the dishes that need to be cooked are less used due to lack of time.It has been found that the prevalence of junk food is increasing regardless of which food the body needs nutrients from.As the living standards of Nepalis have improved, so has the tendency to spend money also increase.This study shows that Nepalis of all age groups are increasingly attracted to junk food.

The study found that students at the school also liked the taste of junk food because they found that junk food was often used in Tiffin. This study shows that unnecessary obesity is on the rise in Nepali society.Due to which, heart related diseases like hypertension, obesity, kidney related diseases, anorexia and other health problems have become widespread at an early age.Thus, while basing the information obtained from the content analysis method, it can be said that junk food in Nepali society is deeply rooted in people of all age groups.

\section{Discussion Conclusions and Recommendations}

Looking at the development and expansion of Nepali society is unbelievable.Due to globalization, it has become common for people from all over the world to come to Nepal and Nepalis also go to 
different parts of the world for various work.In this way a similar change seems to have taken place in the daily life of Nepalese.

Due to the busy schedule of Nepali traditional food, there is no time to cook and junk food is easily available. Thus, the use of junk food in daily life, the interest in the taste of food is growing. Therefore, nutritious food is being replaced by junk food. Junk food is slowly showering the taste of traditional dishes.As Nepali society becomes more and more busy, the consumption of junk food has become widespread due to lack of time. Children, young and old alike have become accustomed to the taste of this type of food. Despite prior knowledge of the problems caused by the consumption of such foods, Nepali society is compelled to use such foods and there is no way to stop it.On the one hand, we have to spend more money on this type of food and on the other hand, we have to invest money in the treatment of adverse health.

Consumption of junk food has negative health effects, which has hampered the development of the country.And it has also had a negative impact on teaching and learning.If the basic food items of Nepal are not prepared due to busyness of parent. the children are totally unknown about the test of Nepali traditional foods.It is unfortunate for us to be made to eat the food we need to eat on a daily basis but to eat the food we need to eat sometimes. The use of junk food may not be eliminated, but its use should be gradually reduced.It is important to start at school.The textbook should include topics about the disadvantages of junk food.At the same time the school should put a complete ban on bringing junk food in tiffin.It is necessary to conduct public awareness programs at the community level about the negative effects of junk food.Such foods need to be included in the fair to promote Nepali traditional food.It seems that the menu should be prepared by giving high priority to Nepali dishes in restaurants, hotels and other places.In this way, the use of junk food has been reduced to less than work and the concerned bodies have to work honestly from their place to make every Nepali healthy.pizza burger ChauminSekuwa meat fried dishes are considered to be the most developed in Nepali society.Plain, salty, sour and spicy dishes are the most sought after items in restaurants. The taste of junk food is hanging on the tongue in all age groups, whether it is a boy or a girl, young or old.Since roasting and roasting destroys almost all the nutrients in the food and the body gets only calories, there is a possibility of unnecessary obesity and various diseases in the body.Not only in urban life but also in rural life of Nepal, the prevalence of this type of food is increasing.Consumption of roasted maize, soybean, bread, haluwa, khir, chamre, chiura, etc., which are traditionally used for breakfast and lunch, has become almost non-existent.The practice of buying and consuming ready-made noodles, biscuits, bhujia, dalmot, namkin, etc. from the market is also increasing in the village life. 


\section{References}

Anderson PM, Butcher KM. Reading, writing and refreshments: Are school Finances Centro buying to children's obesity? Journal of Human Resources, 2006; 41(3):467-494(Google Scholar)

Anderson,ML,MatsaDA. Are Restaurants Really Supersing America? American Economic Journal: Applied Economics 2011;3(1):152-188(Google Scholar)

B.R. Kat, S.L. Rao, and B.A. Chandramouts "Cognitive development in children with chronic protein energy Malnutrition" Behavioural and Brain Functions vol.4 no.1, p.31, 2008(Google Scholar)

BlacksJ.senate drops measures to greatly reduce auger and fat in the food at School Washington Port:2007,Dec15,p. A02(Google Scholar)

Froelish M, Kelly B.(Retrieved2009-02-10),Estimation of quantile treatment effects with STATA:Mimeo2008from http;//www.alexandria. unisg.ch/Publications/46580.

K. Sahoo. B. Sahoo. A.K. Choudhury, N.Y Sofi, R. kumar. and A.S. Bhadoria;"Childhood Obesity; Causes and Consequences" Journal of family medicine and Primary Cart, Vol.4 no. 2, p.187,2015(Google Scholar)

LankfordRD. Junk food: Issues that concern you. Michigan: Green haven Press, 2010p.111-119.

S. Von. Stumas" You are what you eat"? meal type, Socioeconomic Status and Congnitive ability in childhood" Intelligence, vol. 40 no 6p576-583,2012(Google Scholar)

S.Boylan,L.L. Hardly, B.A. Drayton A, Gruneeit, and S Mihrlali"Assessing Junk food Consumption among Australian Children: trends and associated characteristics from a cross-sectional study"BMC Public Health, vol 17, no.1 p.299,2017

T.F. Adversity"Malnutrition at age 3 years and lower Congnitive ability at age 11 years" Archives of Pediatrics and Adolescent Medicine, vol, 157,pp593-600; 2003(Google Scholar) Displaying Jonathan Grix.docx.

Wiles NJ,Birthstone K, Emmett P, LewisG, Junk food diet and Childhood behaviouralproblems:results from the ALSPC Cohort,2009,63(1),491-498 